\title{
Dysregulated miR-645 affects the proliferation and invasion of head and neck cancer cell
}

\author{
Qiang Sun ${ }^{1,2 \dagger}$, Shuai Chen ${ }^{1 \dagger}$, Xue Zhao ${ }^{3}$, Ming Yan ${ }^{4}$, Zheng Fang ${ }^{1}$, Haibin Wang ${ }^{1}$, Junfang Zhao ${ }^{1}$, Minglei Sun ${ }^{1}$, \\ Xinguang Han ${ }^{1}$, Wantao Chen ${ }^{4}$ and Xinming $\mathrm{Li}^{1 *}$
}

\begin{abstract}
Background and purpose: Dysregulated miRNAs play an important role in many malignant tumors. However, elucidating the roles of miRNAs in cancer biology, especially in epithelial cancers, remains an ongoing process. In this study, we identified the differentially expressed miR-645 in the progressing of head and neck squamous cell carcinoma (HNSCC) and investigated its biological function.

Methods: The association between clinicopathological parameters and the expression levels of the candidated miRNAs were analyzed by using the Kaplan-Meier survival analysis. The cell growth, invasion and migration potential, and clone formation were observed to detect the functions of the miRNAs in HNSCC cells.

Results: In the 34 HNSCC tissues with lymph node metastasis, the expression level of miR-645 was $0.54 \pm 0.12$, and the expression level was $0.22 \pm 0.05$ in the 28 tissues with non lymph node metastasis $(p=0.017)$. In patients with HNSCC, higher level of miR-645 expression significantly correlates with worse overall survival $(p=0.04)$. Ectopic expression of miR-645 promoted cell invasion and migration.
\end{abstract}

Conclusions: miR-645 play a key role in cell invasion and metastasis and their expression correlates with overall survival in the patients with HNSCC.

Keywords: miR-645, HNSCC, Growth, Metastasis, Invasion

\section{Background}

MicroRNAs (miRNAs) are endogenous RNAs that play important gene-regulatory roles in animals via sequencespecific interactions with the $3^{\prime} \mathrm{UTR}$ of cognate mRNA targets, causing suppression of translation and mRNA decay $[1,2]$. Nucleotides $2-7$, from the $5^{\prime}$ end of the miRNAs, are referred to as the "seed" and are critical for hybridization to the targets [3], It has been firmly established that miRNAs regulate many key cellular processes such as cell growth, differentiation and apoptosis [4, 5]. Subsets of miRNAs have been identified as potential diagnostic and prognostic markers in malignant tumors

\footnotetext{
*Correspondence: Ixmingsuccess@sina.com

${ }^{\dagger}$ Qiang Sun and Shuai Chen contributed equally to this work

1 Department of Stomatology, The First Affiliated Hospital of Zhengzhou

University, No. 1, East Jian she Road, Zhengzhou 450052, Henan, China

Full list of author information is available at the end of the article
}

[6-8]. Many evidences suggest that the regulatory capacity of miRNAs is dysregulated and exploited in malignant tumors [9]. Several miRNAs are up-regulated in specific tumors appears a general trait of human cancers which playing a causal role in the transformed phenotype [1012], and the mechanisms are remain to be known further. Although the number of verified human miRNAs is still expanding, the functions of only a few of them have been described.

Head and neck squamous cell carcinoma (HNSCC) ranks sixth among cancers worldwide [13], includes tumors of the oral cavity, oropharynx, and larynx. Survival rates for HNSCC have remained unchanged throughout the last three decades, and half of all cases die within 5 years of diagnosis [11]. The presence of lymph node metastasis affects more than $50 \%$ of HNSCC patients and it is one of the most important prognostic 
indicators associated with poor long survival rates [14, 15]. There are some biomarkers for the classification diagnosis, individual treatment and prognosis of HNSCC investigated by miRNAs array and studies have shown altered miRNAs profiles in HNSCC compared to their normal tissue [16-21]. $m i R-645$ has been reported to be disrupt-expression in pathological states [22-25], however, the role of $m i R-645$ in metastasis of cancer has not been reported.

In this study, we examined the expression of $m i R-645$ in HNSCC samples by gene chips and further confirmed in HNSCC samples and HNSCC cell lines using real-time PCR. We found that miR-645 levels were up-regulated in HNSCC tissues and highly invasive cell lines. Furthermore, we have investigated the mechanism of $m i R-645$ in HNSCC cancer cell lines. These results show that exogenous overexpression of $m i R-645$ promotes the invasion and migration of HNSCC cells in vitro.

\section{Methods}

\section{Cell culture}

The human HNSCC cell lines, HN4 and HN12 were kindly provided by Shanghai Key Laboratory of Stomatology [26-30]. These cell lines were cultured in DMEM supplemented with $10 \%$ heat-inactivated FBS (GIBCO BRL, NY, USA), penicillin (100 units $/ \mathrm{ml}$ ) and streptomycin $(100 \mu \mathrm{g} / \mathrm{ml})$ at $37{ }^{\circ} \mathrm{C}$ in a humidified $5 \% \mathrm{CO}_{2}$ atmosphere.

\section{Tissue samples and reagents}

Tissue samples from patients undergoing curative treatment for definitely diagnosed HNSCC were obtained by surgery, with half of each sample quickly frozen in liquid nitrogen and stored at $-80^{\circ} \mathrm{C}$ until use and the other half embedded in paraffin for pathological examination. All patients selected in the study were informed consent in advance. In parallel, a separate cohort of 47 patients also was assembled from a large pool of patients in the database based on histologic diagnosis of HNSCC who had undergone radical surgery. We retrospectively reviewed the medical records of patients with HNSCC. In this study, we retrospectively reviewed the medical records of patients. Total RNAs were extracted from paraffin blocks using the high pure miRNA isolation kit according to the manufacturer's protocol (Roche, Switzerland) before further analysis.

Both the miR-645 inhibitor and its mimics were purchased from GenePharma (Shanghai, China). The high pure miRNA isolation kit was purchased from Roche (Basel, Switzerland). The miRcute miRNA qPCR detection kit and miRcute miRNA qPCR detection kit were purchased from TIANGEN BIOTECH (Beijing, China).

\section{Invasion assays and wound-healing experiment}

In vitro invasion assays were performed to analyze the invasive potential. A total of $8 \times 10^{4}$ various cells in $200 \mu \mathrm{l}$ serum-free DMEM medium were plated onto BD BioCoat $^{\mathrm{TM}}$ Matrigel $^{\mathrm{TM}}$ Invasion Chamber $(8 \mu \mathrm{m}$ pore size; BD Biosciences) and the lower chamber was immediately filled with $500 \mu \mathrm{l}$ of DMEM medium with $10 \%$ FBS as a chemoattractant. After $24 \mathrm{~h}$ of incubation in a humidified atmosphere containing $5 \% \mathrm{CO}_{2}$ at $37^{\circ} \mathrm{C}$, the non-invading cells are removed from the upper surface of the membrane by a cotton swab and the membranes were then fixed with methanol and stained by $0.2 \%$ crystal violet. For woundhealing experiments, cells were plated in 6-well plates, transfected as indicated, and cultured to confluency. Cells were serum-starved and scraped with a P200 tip (time 0), and the number of migrating cells is counted from pictures (5 fields) taken at the indicated time points.

\section{Clony formation}

Twenty-four hours after transfection, HNSCC cells $\left(1 \times 10^{5}\right.$ cells per plate) were plated in $100-\mathrm{mm}$ culture dishes and incubated with $600 \mu \mathrm{g} / \mathrm{ml} \mathrm{G418} \mathrm{in} \mathrm{final} \mathrm{con-}$ centration for 14 days to allow colonies formation. The colonies were then washed twice with PBS, fixed with $70 \%$ ethanol and stained with Coomassie Blue. Colonies of more than 50 cells were counted under a dissecting microscope. The data from colony formation were showed as mean \pm SD from at least three independent experiments, each being performed in triplicate.

\section{Statistical analysis}

Statistical analyses for real-time PCR and the in vitro analysis were performed with software from SPSS 13.0 (standard version 13.0; SPSS Inc., Chicago, IL, USA). The results of the cell proliferation assay, colony formation assay, and in vitro invasion assay were evaluated by Student's $t$ tests. Patients were divided in two groups based on the median of the miR-645 expression values. Tumors were then classified as high miR-645 group if the expression value was equal to or above the median and as low $m i R-645$ group if the expression value was below the median. The correlation between $m i R-645$ expression and the disease-free survival probability were estimated by using Kaplan-Meier survival analysis. A $P<0.05$ was taken as the level of significance.

\section{Results}

The association of miR-645 expression with metastatic rates in patients with HNSCC

We first measured mature $m i R-645$ levels in a group of tissue specimens from the HNSCC patients. In the 76 HNSCC tissues with lymph node metastasis, the 
expression level of $m i R-645$ was $2.71 \pm 0.24$, and the expression level was $1.58 \pm 0.23$ in the 51 tissues with non lymph node metastasis $(p=0.001$, Fig. 1a). The results showed that the miR-645 expression level in the primary HNSCC samples with lymph node metastasis was significantly higher than that in the tissues without lymph node metastasis. The correlations between the miR-645 expression level and clinical pathological characteristics of are summarized in Table 1. Statistically significant associations between the miR-645 expression levels and metastatic rates were observed. In the HNSCC tissues with severe histological signs (vascular emboli, perineural invasion, diffuse infiltration), the expression level of miR-645 was also significantly higher than the expression level in the tissues with non-severe histological signs (Fig. 1c-e). However, there was no significant correlation between the expression level of miR-645 and age, sex, tumor size, site, smoking history, alcohol history (Table 1).

We next measured mature miR-645 levels in a collection of HNSCC patients with clinical history. Patients were divided in two groups, with, respectively high or low levels of miR-645. Remarkably, when tested using the Kaplan-Meier survival analysis, the miR-645 "low" group displayed a significant longer disease-free survival when compared to the "high" group (Fig. 1b). These data suggested a possible link between miR-645 expression and tumor progression.

\section{miR-645 promotes cell proliferation}

HN4 and HN12 cell lines were established from primary HNSCC tissue and the lymph node metastatic tissue from the same patient, respectively. We used these cell lines to investigate how gain or loss of function of miR-645 impacted cell biological behavior. The HN12 cells displayed high migration capacities and contained a relatively high level of miR-645 (Fig. 2a). First, we assessed the growth of miR-645-transfected and miRNC-transfected HN4 cells after transient transfection. As shown in Fig. 2b, miR-645 was able to increase the proliferation of miR-645-transfected cells compared with miR-NC-transfected cells significantly at day 3 and 5 ( $P<0.05$, Student's $t$ test) (Fig. 2b). We further tested if endogenous expression of $m i R-645$ was required for
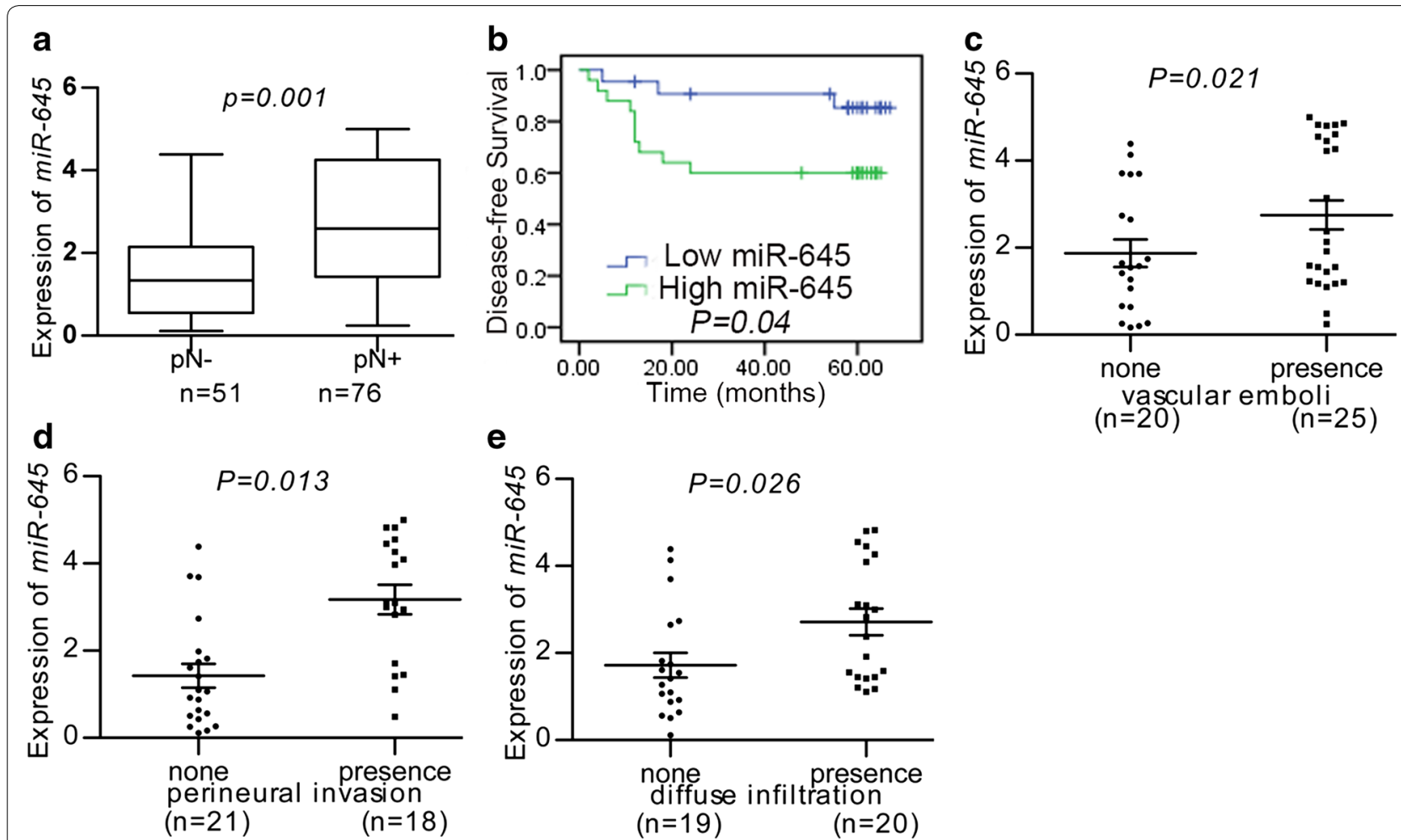

Fig. 1 Clinical association of miR-645 with HNSCC patients. a Mature miR-645 levels were measured in HNSCC samples by real-time PCR. b KaplanMeier graph representing the probability of disease-free survival in HNSCC patients from the "Milan-INT" dataset stratified. The log-rank test $P$ value reflects the significance of the association between low miR-645 level and disease-free survival. c-e Mature miR-645 levels were compared between HNSCC samples with severe histological signs (vascular emboli, perineural invasion, diffuse infiltration) and the tissues with non-severe histological signs by real-time $P C R$ 
Table 1 Associations between miR-645 and clinical parameters $(n=62)$

\begin{tabular}{|c|c|c|c|c|}
\hline \multirow[t]{2}{*}{ Characteristic } & \multicolumn{2}{|c|}{ No. of patients } & \multirow{2}{*}{$\begin{array}{l}\text { miR-645 } \Delta \mathrm{Ct}^{\mathrm{a}} \\
\text { Mean } \pm \text { SD }\end{array}$} & \multirow[t]{2}{*}{$P$} \\
\hline & No. & $\%$ & & \\
\hline \multicolumn{5}{|l|}{ Age, years } \\
\hline$\geq 60$ & 26 & 41.9 & $0.29 \pm 0.08$ & \multirow[t]{2}{*}{0.173} \\
\hline$<60$ & 36 & 58.1 & $0.48 \pm 0.11$ & \\
\hline \multicolumn{5}{|l|}{ Sex } \\
\hline Male & 43 & 69.4 & $0.37 \pm 0.09$ & \multirow[t]{2}{*}{0.625} \\
\hline Female & 19 & 30.6 & $0.45 \pm 0.13$ & \\
\hline \multicolumn{5}{|l|}{ Pathologe grade } \\
\hline 1 & 26 & 42.6 & $0.22 \pm 0.076$ & \multirow[t]{3}{*}{0.025} \\
\hline$\|$ & 27 & 44.3 & $0.46 \pm 0.12$ & \\
\hline III & 8 & 13.1 & $0.82 \pm 0.21$ & \\
\hline \multicolumn{5}{|l|}{ T stage } \\
\hline $\mathrm{T} 1,2$ & 27 & 43.5 & $0.34 \pm 0.08$ & \multirow[t]{2}{*}{0.406} \\
\hline $\mathrm{T} 3,4$ & 34 & 54.8 & $0.46 \pm 0.11$ & \\
\hline \multicolumn{5}{|l|}{ N stage } \\
\hline $\mathrm{pN}-$ & 28 & 45.2 & $0.22 \pm 0.05$ & \multirow[t]{2}{*}{0.017} \\
\hline $\mathrm{pN}+$ & 34 & 54.8 & $0.54 \pm 0.12$ & \\
\hline \multicolumn{5}{|l|}{ Site } \\
\hline Tongue & 25 & 41.7 & $0.32 \pm 0.11$ & \multirow[t]{5}{*}{0.514} \\
\hline Gingival & 12 & 20.0 & $0.44 \pm 0.18$ & \\
\hline Cheek & 7 & 11.7 & $0.35 \pm 0.16$ & \\
\hline Floor of mouth & 11 & 18.3 & $0.34 \pm 0.15$ & \\
\hline Oropharynx & 5 & 8.3 & $0.80 \pm 0.41$ & \\
\hline \multicolumn{5}{|c|}{ Histologic signs of severity (vascular emboli, perineural invasion, diffuse infiltration) } \\
\hline None & 26 & 41.9 & $0.28 \pm 0.05$ & \multirow[t]{2}{*}{0.024} \\
\hline Presence & 21 & 33.9 & $0.60 \pm 0.13$ & \\
\hline \multicolumn{5}{|l|}{ Smoking history } \\
\hline Nonsmoker & 28 & 45.2 & $0.41 \pm 0.09$ & \multirow[t]{2}{*}{0.452} \\
\hline Smoker & 30 & 48.4 & $0.32 \pm 0.07$ & \\
\hline \multicolumn{5}{|l|}{ Alcohol history } \\
\hline Nondrinker & 38 & 61.3 & $0.41 \pm 0.08$ & \multirow[t]{2}{*}{0.339} \\
\hline Drinker & 20 & 32.3 & $0.29 \pm 0.07$ & \\
\hline
\end{tabular}

$S D$ standard deviation, $T$ tumor stage, $N$ lymphnode stage

a $\Delta \mathrm{Ct}$ indicates the difference in the cycle number at which a sample's fluorescent signal passes a given threshold above baseline (Ct) derived from a specific gene compared with that of $U 6$ in tumor tissues

HNSCC invasion in the cancer cell line HN12. For this purpose, we silenced miR-645 and this treatment led to an approximately 1.5 -fold decline in growth properties (Fig. 2c).

Ectopic expression of miR-645 promotes cancer metastasis In light of the preceding data, we aimed to determine more directly if $m i R-645$ plays a causal role in the aggressive traits of HNSCC cancer cells. We used this cell line to investigate how gain or loss of function of $m i R$ 645 impacted cell migration and invasion, which are hallmarks of metastatic capacity. In the transwell assays shown in Fig. 3b, down regulation of miR-645 in HN12 cells decreased invasive abilities 1.6-fold compared to the same cells expressing miR-NC. We further tested if endogenous expression of $m i R-645$ was required for cell invasion in HNSCC cancer cell line HN4. For this purpose, we upregulated $m i R-645$ and this treatment led to an approximately 1.8 -fold augmentation in invasive properties (Fig. 3a). Furthermore, the pro-migration effects of $m i R-645$ were observed in wound-healing assays in HN4 and HN12 cells (Fig. 3c, d). 

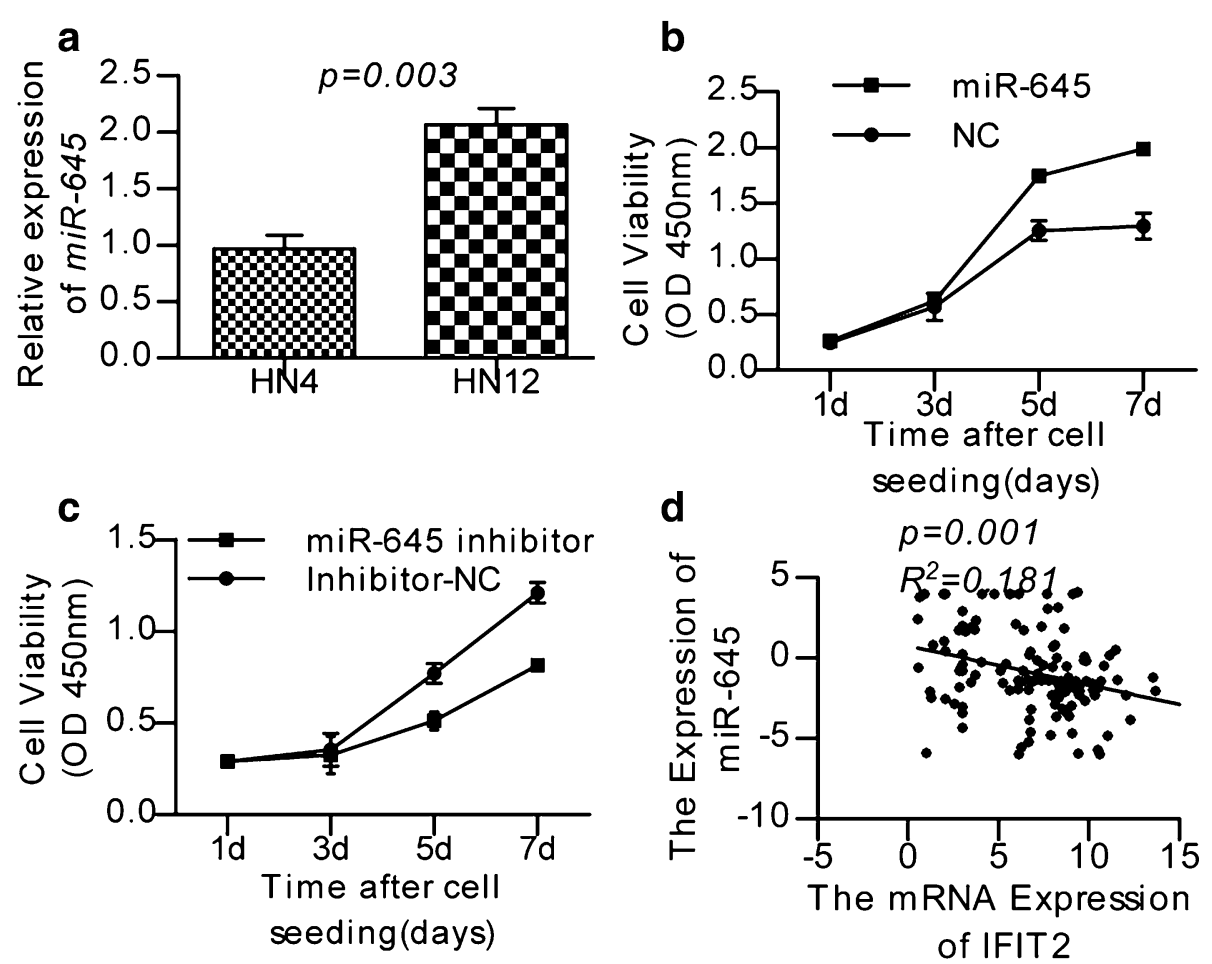

Fig. 2 miR-645 promotes HNSCC. a Expression levels of miR-645 in cellular models of metastatic progression were tested by real-time PCR. Values related to the nonmetastatic, less aggressive cell line (HN4) are normalised to U6 and shown as the mean and SD. b, c Cell growth curves: proliferation of phenotypically stable indicated cell lines was monitored by the CCK-8 assay. $\mathbf{d}$ Linear regression analyse the correlation between miR-645 and IFIT2

\section{Ectopic expression of miR-645 promotes single cell clone proliferation}

Single cell clone proliferation ability is considered to be hallmarks of metastatic capacity. We aimed to determine more directly if $m i R-645$ improve the single cell clone proliferation ability. We used this cell line to investigate how gain or loss of function of miR-645 impacted the single cell clone proliferation ability. In the clony formation shown in Fig. 4a, up-regulation of $m i R-645$ in HN4 cells increased single cell clone proliferation ability $1.5-$ fold compared to the same cells expressing miR-NC. We further tested if endogenous expression of $m i R-645$ was required for cell invasion in HNSCC cancer cell line HN12. For this purpose, we down-regulated miR-645 and this treatment led to an approximately 1.6-fold reduction in single cell clone proliferation properties (Fig. 4b).

\section{Discussion}

Although a global reduction of miRNA abundance appears to be a general trait of human cancers, playing a causal role in the metastatic phenotype [11, 12, 31], several miRNAs are up-regulated in tumors [10], recently, miRNAs have been shown to be related to tumor metastasis [30], providing a new perspective on the metastatic process. Nonetheless, The role of miRNAs in HNSCC has been widely investigated. Here, we will focus on miRNA645 promotes HNSCC cancer metastasis.

In this study, we described for the first time the miR645 is markly upregulated in metastatic HNSCC in large samples. We also found that miR-645 is closely related to the cancer metastasis and $m i R-645$ "high expression" group displayed a significantly poorer disease-free survival rates. The $m i R-645$ promote the HNSCC cells proliferation, invasion, migration and the single cell clone proliferation ability. The properties is the malignant characters of oncogenes. We have proven that the down-regulation of miR-645 is crucial in HNSCC metastasis and demonstrated that $m i R-645$ acts as a putative oncogene.

Recently, miRNAs have been proved to be related with tumor metastasis [32-34], providing a new perspective on the metastatic process. Nonetheless, the role of miRNAs in HNSCC metastasis is little known. This study first proves that $m i R-645$ is up-regulated in metastatic HNSCC. Aberrant patterns of miRNA expression are implicated in human diseases including HNSCC. miR-645 plays a variety of important functions in physiology and pathology [22, 24]. Recent literature reports that the miR-645 play important effort in the malignant 

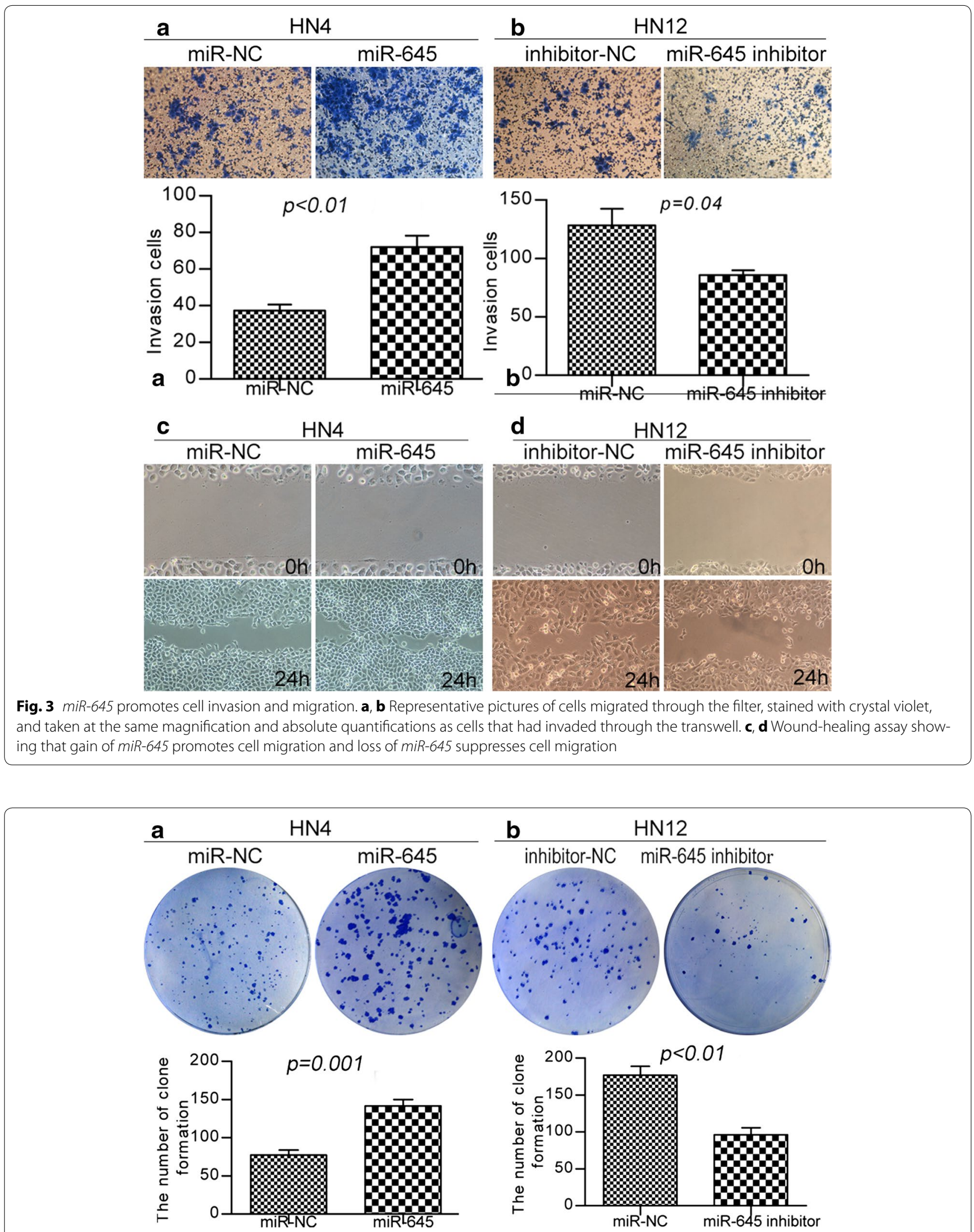

Fig. 4 miR-645 promotes single cell clone proliferation. a, b Representative pictures of single cell clone proliferation, stained with crystal violet, colony formation assay in the group of $1 \times 105$ cells for miR-NC transfected and miR-645-transfected cells 
progressing of ovarian cancer and adenocarcinoma of gastric esophagea $[23,25]$. As miRNAs function mainly through the inhibition of multiple target genes and study report that miR-645 inhibits apoptosis by targeting tumor suppressor IFIT2 [25]. In our study, the inverse correlation between miR-645 and IFIT2 was confirmed by real-time PCR in the panel of 127 HNSCC tissues. We support that the IFIT2 may be the target gene of miR-645 (Fig. 2d). Meantime we support that the miRNAs play their efforts though the complicate gene net. This result may preliminary explain the function of $m i R-645$, but the mechanism is still to be research.

\section{Conclusion}

In conclusion, our results have proven that miR-645 plays a causal role in the metastases of HNSCC. These findings have implications for understanding the mechanism of HNSCC, and miR-645 may be a valuable maker and target for prevention or adjuvant therapy in HNSCC.

\section{Authors' contributions}

QS, SC, XZ, ZF carried out the molecular studies. QS drafted the manuscript. WC, XL, QS participated in the design of the study. XH, MS performed the statistical analysis. MY, JZ conceived of the study, and participated in its design and coordination. SC helped to draft the manuscript. All authors read and approved the final manuscript.

\section{Author details \\ ${ }^{1}$ Department of Stomatology, The First Affiliated Hospital of Zhengzhou Uni- versity, No. 1, East Jian she Road, Zhengzhou 450052, Henan, China. ${ }^{2}$ Institute of Clinical Medicine, The First Affiliated Hospital of Zhengzhou University, No. 1, East Jian she Road, Zhengzhou 450052, Henan, China. ${ }^{3}$ Department of Neu- roimmunology Research, The Henan Academy of Medical and Pharmacologic Sciences, Zheng-Zhou University, Daxue Rd No. 40, Zhengzhou 450052, Henan, China. ${ }^{4}$ Department of Oral and Maxillofacial-Head and Neck Oncol- ogy, Ninth People's Hospital, Shanghai Jiao Tong University School of Medi- cine, Shanghai 200011, China.}

\section{Acknowledgements}

The human HNSCC cell lines, HN4 and HN12 were kindly provided by Shanghai Key Laboratory of Stomatology.

\section{Grant support}

This work was supported by Grants of the National Natural Science Foundation of China (NSFC 81402231), the basic and frontier technology research projects by Science and Technology Department of Henan province (142300410315) and the funding from Youth Foundation of The First Affiliated Hospital of Zhengzhou University and the oral and maxillofacial surgery academician workstation of Zhengzhou (152PYSGZ040).

\section{Compliance with ethical guidelines}

\section{Competing interests}

The authors declare that they have no competing interests.

Received: 9 July 2015 Accepted: 3 September 2015

Published online: 17 September 2015

\footnotetext{
References

1. Bartel DP. MicroRNAs: target recognition and regulatory functions. Cell. 2009;136(2):215-33.
}

2. Ambros V. The functions of animal microRNAs. Nature. 2004;431(7006):350-5.

3. Guo H, Ingolia NT, Weissman JS, Bartel DP. Mammalian microRNAs predominantly act to decrease target mRNA levels. Nature. 2010;466(7308):835-40.

4. Schickel R, Boyerinas B, Park SM, Peter ME. MicroRNAs: key players in the immune system, differentiation, tumorigenesis and cell death. Oncogene. 2008;27(45):5959-74.

5. Zhang J, Guo H, Qian G, Ge S, Ji H, Hu X, Chen W. MiR-145, a new regulator of the DNA fragmentation factor-45 (DFF45)-mediated apoptotic network. Mol Cancer. 2010;9:211.

6. Kent OA, Mendell JT. A small piece in the cancer puzzle: microRNAs as tumor suppressors and oncogenes. Oncogene. 2006;25(46):6188-96.

7. Calin GA, Croce CM. MicroRNA signatures in human cancers. Nat Rev Cancer. 2006;6(11):857-66

8. Hou J, Lin L, Zhou W, Wang Z, Ding G, Dong Q, Qin L, Wu X, Zheng Y, Yang $Y$, et al. Identification of miRNomes in human liver and hepatocellular carcinoma reveals miR-199a/b-3p as therapeutic target for hepatocellular carcinoma. Cancer Cell. 2011;19(2):232-43.

9. Ventura A, Jacks T. MicroRNAs and cancer: short RNAs go a long way. Cell. 2009;136(4):586-91.

10. Volinia S, Calin GA, Liu CG, Ambs S, Cimmino A, Petrocca F, Visone R, Iorio $M$, Roldo $C$, Ferracin $M$, et al. A microRNA expression signature of human solid tumors defines cancer gene targets. Proc Natl Acad Sci USA. 2006;103(7):2257-61.

11. Kumar MS, Lu J, Mercer KL, Golub TR, Jacks T. Impaired microRNA processing enhances cellular transformation and tumorigenesis. Nat Genet. 2007;39(5):673-7.

12. Ozen M, Creighton CJ, Ozdemir M, Ittmann M. Widespread deregulation of microRNA expression in human prostate cancer. Oncogene. 2008;27(12):1788-93.

13. Tran N, Rose BR, O'Brien CJ. Role of human papillomavirus in the etiology of head and neck cancer. Head Neck. 2007;29(1):64-70.

14. Ferlito A, Rinaldo A, Devaney KO, MacLennan K, Myers JN, Petruzzelli GJ, Shaha AR, Genden EM, Johnson JT, de Carvalho MB, et al. Prognostic significance of microscopic and macroscopic extracapsular spread from metastatic tumor in the cervical lymph nodes. Oral Oncol. 2002;38(8):747-51.

15. Kowalski LP, Sanabria A. Elective neck dissection in oral carcinoma: a critical review of the evidence. Acta Otorhinolaryngol Italica Organo Ufficiale Della Societa Italiana di Otorinolaringologia e Chirurgia Cervico-Facciale. 2007;27(3):113-7.

16. Ramdas L, Giri U, Ashorn CL, Coombes KR, El-Naggar A, Ang KK, Story MD. miRNA expression profiles in head and neck squamous cell carcinoma and adjacent normal tissue. Head Neck. 2009;31 (5):642-54.

17. Wong TS, Liu XB, Chung-Wai Ho A, Po-Wing Yuen A, Wai-Man Ng R, Ignace Wei W. Identification of pyruvate kinase type $\mathrm{M} 2$ as potential oncoprotein in squamous cell carcinoma of tongue through microRNA profiling. Int J Cancer. 2008;123(2):251-7.

18. Childs G, Fazzari M, Kung G, Kawachi N, Brandwein-Gensler M, McLemore M, Chen Q, Burk RD, Smith RV, Prystowsky MB, et al. Lowlevel expression of microRNAs let-7d and miR-205 are prognostic markers of head and neck squamous cell carcinoma. Am J Pathol. 2009;174(3):736-45

19. Hui AB, Lenarduzzi M, Krushel T, Waldron L, Pintilie M, Shi W, PerezOrdonez B, Jurisica I, O'Sullivan B, Waldron J, et al. Comprehensive MicroRNA profiling for head and neck squamous cell carcinomas. Clin Cancer Res Off J Am Assoc Cancer Res. 2010;16(4):1129-39.

20. Chang SS, Jiang WW, Smith I, Poeta LM, Begum S, Glazer C, Shan S, Westra W, Sidransky D, Califano JA. MicroRNA alterations in head and neck squamous cell carcinoma. Int J Cancer. 2008;123(12):2791-7.

21. Avissar M, Christensen BC, Kelsey KT, Marsit CJ. MicroRNA expression ratio is predictive of head and neck squamous cell carcinoma. Clin Cancer Res. 2009;15(8):2850-5.

22. Zhong Y, Pei YH, Wang J, Chen J, Jiang SS, Gong JB. MicroRNA expression profile in myocardial bridging patients. Scand J Clin Lab Invest. 2014;74(7):582-7.

23. Shih KK, Qin LX, Tanner EJ, Zhou Q, Bisogna M, Dao F, Olvera N, Viale A, Barakat RR, Levine DA. A microRNA survival signature (MiSS) for advanced ovarian cancer. Gynecol Oncol. 2011;121(3):444-50 
24. Rosenbluth EM, Shelton DN, Wells LM, Sparks AE, Van Voorhis BJ. Human embryos secrete microRNAs into culture media-a potential biomarker for implantation. Fertil Steril. 2014;101(5):1493-500.

25. Feng X, Wang Y, Ma Z, Yang R, Liang S, Zhang M, Song S, Li S, Liu G, Fan D, et al. MicroRNA-645, up-regulated in human adencarcinoma of gastric esophageal junction, inhibits apoptosis by targeting tumor suppressor IFIT2. BMC Cancer. 2014;14:633.

26. Miyazaki H, Patel V, Wang H, Ensley JF, Gutkind JS, Yeudall WA. Growth factor-sensitive molecular targets identified in primary and metastatic head and neck squamous cell carcinoma using microarray analysis. Oral Oncol. 2006:42(3):240-56.

27. Yeudall WA, Crawford RY, Ensley JF, Robbins KC. MTS1/CDK4I is altered in cell lines derived from primary and metastatic oral squamous cell carcinoma. Carcinogenesis. 1994;15(12):2683-6.

28. Benke EM, Ji Y, Patel V, Wang H, Miyazaki H, Yeudall WA. VEGF-C contributes to head and neck squamous cell carcinoma growth and motility. Oral Oncol. 2010;46(4):e19-24.

29. Wang H, Patel V, Miyazaki H, Gutkind JS, Yeudall WA. Role for EPS8 in squamous carcinogenesis. Carcinogenesis. 2009;30(1):165-74.
30. Sun Q, Zhang J, Cao W, Wang X, Xu Q, Yan M, Wu X, Chen W. Dysregulated miR-363 affects head and neck cancer invasion and metastasis by targeting podoplanin. Int J Biochem Cell Biol. 2013;45(3):513-20.

31. Lu J, Getz G, Miska EA, Alvarez-Saavedra E, Lamb J, Peck D, Sweet-Cordero A, Ebert BL, Mak RH, Ferrando AA, et al. MicroRNA expression profiles classify human cancers. Nature. 2005;435(7043):834-8.

32. Shoushtari AN, Szmulewitz RZ, Rinker-Schaeffer CW. Metastasis-suppressor genes in clinical practice: lost in translation? Nature Rev Clin Oncol. 2011:8(6):333-42.

33. Lujambio A, Calin GA, Villanueva A, Ropero S, Sanchez-Cespedes M, Blanco D, Montuenga LM, Rossi S, Nicoloso MS, Faller WJ, et al. A microRNA DNA methylation signature for human cancer metastasis. Proc Natl Acad Sci USA. 2008;105(36):13556-61.

34. Tavazoie SF, Alarcon C, Oskarsson T, Padua D, Wang Q, Bos PD, Gerald WL, Massague J. Endogenous human microRNAs that suppress breast cancer metastasis. Nature. 2008;451(7175):147-52

\section{Submit your next manuscript to BioMed Central and take full advantage of:}

- Convenient online submission

- Thorough peer review

- No space constraints or color figure charges

- Immediate publication on acceptance

- Inclusion in PubMed, CAS, Scopus and Google Scholar

- Research which is freely available for redistribution

Submit your manuscript at

www.biomedcentral.com/submit

C Biomed Central 